\title{
Akutní stavy v interní medicíně
}

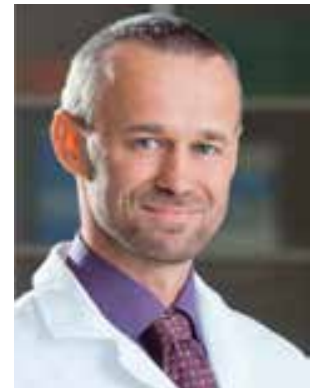

Milé kolegyně, vážení kolegové, přátelé časopisu Vnitřní lékařství,

internisté pracující v nemocnicích se den co den setkávají s pacienty, u nichž došlo nebo bezprostředně hrozí akutní zhoršení zdravotního stavu. Internisté ale neřeší pouze akutní stavy v rámci svých standardních oddělení, prípadně jednotek intenzivní péče (JIP), ale podílejí se zásadním způsobem na jejich řešení na urgentních př́ijmech a v rámci konziliární činnosti napřič všemi obory dané nemocnice. V USA a Kanadě dokonce vzniká nový pojem hospitalist, tj. internista, který svou profesi výhradně zaměřil na poskytování diagnosticko-léčebné péče hospitalizovaným pacientům, a je tudíž vystaven nutnosti ovládat široké spektrum naléhavých situací. I když ne všichni "hospitalisté" musí být nevyhnutně internisté, nároky na šiři znalostí předurčuji internisty k plnění této vůdčí role uvnitř nemocnic. Internista pracující v nemocnici také sehrává zcela klíčovou roli v procesu včasného rozpoznávání rizikových pacientů, u kterých hrozí akutní deteriorace stavu. A nejen to. Lékař musí umět rozpoznat situace, $v$ nichž již není bezpečné léčit pacienta v rámci standardního oddělení a je nutná úzká spolupráce s intenzivistou. Měl by být také vzděláván ve schopnostech posoudit, kdy rozšiřování léčby akutních stavů o náročnou péči na JIP již není ve prospěch nemocného. Je tedy více než zrejmé, že dovednost vyhodnotit a správně řešit náhlé změny zdravotního stavu je jedním ze základních a neoddiskutovatelných piliřů dobrého internisty. To je také důvodem, proč jeden celý blok otázek pro atestující z vnitřního lékařství je věnován problematice akutních stavů. Vědecké poznatky v oblasti intenzivní péče se v posledních letech dramaticky vyvíjejí. Poskytování čerstvých a relevantních informací je společně s mentorstvím přímo u lůžka nemocného základním krokem $k$ dosažení společného cíle - poskytování vysoce kvalitní péče o akutně nemocné. I když nám šíře akutní medicíny neumožňuje vyčerpávajícím zpưsobem danou oblast pokrýt, věríme společně se všemi autory následujících monotematických čísel časopisu Vnitřní lékařství, že si v následujících raádcích užitečnou informaci najdou jak lékaři v přípravě k atestaci, tak i zkušení internisté.

Váš



prof. MUDr. Martin Matějovič, Ph.D., FCMA

místopředseda České společnosti intenzivní medicíny České lékařské společnosti J. E. Purkyně a spolueditor tohoto čísla časopisu Vnitřní lékařství

Plzeň, únor 2019 